\title{
Colloquy
}

\section{THE DYING HOME: "Bad Deaths" and Spatial Inscriptions of Mourning in a Favela}

\author{
EUGÊNIA MOTTA \\ Universidade do Estado do Rio de Janeiro \\ (D) https:/ / orcid.org/0000-0001-9491-0993
}

I overheard many conversations Maria had with friends, relatives, and neighbors we met on walks through the Aliança favela in Rio de Janeiro. ${ }^{1}$ This community forms part of the Complexo do Alemão, a 0.8 square-mile region across a number of hills and valleys, with favelas that constitute a continuous, densely occupied region with close to seventy thousand people. A visit to the market with Maria could take hours because of these meetings. She spoke of various topics: from gossip about acquaintances' extramarital affairs to serious issues like the functioning of schools and public health clinics. At times Maria spoke of her son, Wellington, and would ask other women: "Have you also lost one?"

This is how Maria confirmed if her interlocutor also had a son who had been assassinated. The brief question, quickly understood and often responded to in the affirmative, expressed how common it is for young favela residents, especially Black youth, to be killed in armed conflicts, leaving mothers in constant mourning. Many of these murders are perpetrated by the police and have a clearly racist character. Rio de Janeiro's official data shows an alarming increase in this type of execution in recent years, and many deaths are not formally registered, hidden by what are officially treated as disappearances. ${ }^{2}$ 
Unlike deaths due to age and that correspond to the chronological order of generations, these deaths are conceived of and experienced by entire communities as "bad deaths." They last longer, spread daily through space and among many people, require large interpretive efforts, and place collective futures at risk. One of the main ways that this finds expression is through different modalities of inscription in homes. Transformations in the organization of furniture, the construction of domestic altars, and graffiti on walls speak to the entanglement between the material and social in house-ing processes (see Costa Oliveira and Fausto 2021, this issue), as bad deaths can convert homes and neighborhoods from places of life and living into places of death and dying.

Wellington was eighteen when he fell victim to police brutality. The violence, the "cowardliness" — as Maria said — attributed such a negative character to his death that it wound up extending to the death of his mother and to the dying of their house. Maria's death constituted a prolongment of her mourning for her son, expressed by interactions between her and the houses where she lived. Maria's personhood was made and remade through these fatal experiences that engendered a process of de-house-ing (also present in the oikographies of Federico Neiburg [2021, this issue] and Ryo Morimoto [2021, this issue]).

When Wellington began to work in accounting for the local drug trade, Maria did everything she could for him to give it up. She sold the house where she lived with the boy and her husband and quickly bought another. This first house had been built gradually, with money saved by the couple. It had attributes of a "good house," as Maria told me: the size of the rooms, the pretty decorations, the tall wall in front, and having resulted from the couple's efforts, all becoming an omen for a good future for the family. In contrast, the home to which Maria would move, and in which she lived when I met her, was a "bad house." The poor air circulation and the uncomfortable position of the furniture constituted the ways by which she spoke of this house (Motta 2020).

The reciprocal actions of humans on houses and of houses on humans form part of a continuous process (i.e., house-ing) that co-produces each of them as persons. I consider personhood, in the case of houses or humans, as the articulation of three capacities: that of existing in relation and in the world, that is, to be constituted as a relatively autonomous entity while in communication with others; that of having a biography, a coherent and diachronic set of events; and that of acting morally, that is, of behaving based on notions of what is good or fair and their opposites. The interlocking personhood of humans and houses is therefore the dynamic co-constitution of singular existences, particular histories, and agency. 
Maria and her husband made a good house, which in turn made them people honored in the community, as were their children. The other house acquired after the involvement of the son with drug dealing, in turn, resulted from desperation and shame, leaving Maria permanently upset and then ill.

The first time I entered Maria's house I noted the image that took up part of the wall in front of the entrance. It was a photo of Wellington smiling, his two hands giving a thumbs-up, and his silhouette set against the image of a blue sky with white clouds. Below stood the word Saudade.

One finds the same word written on walls throughout the favela, next to male names of victims of murder, usually perpetrated by the police. It is a cliché that the term saudade only exists in Portuguese. ${ }^{3}$ It refers to the sense of loss and lament for a person or a thing distant in time or space. Saudade is also what is felt in mourning. In the favela, the graffiti on the walls indicates the locations where people were killed. These are inscriptions of mourning on and outside houses, expanding the spatiality of grief for bad deaths and demonstrating the porosity of inside and outside proper to house-ing. The anonymous writings also offer an implicit criticism of police action, an affirmation that this violence is not forgotten.

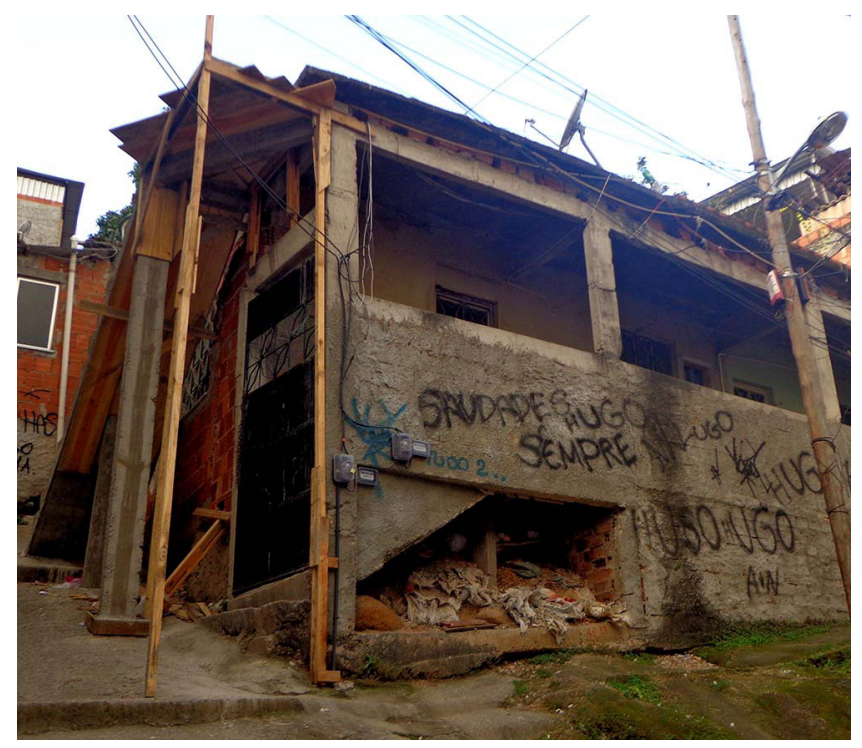

Figure 1. Graffiti mourning the death of a youth in a Rio de Janeiro favela. Photo by Eugênia Motta.

Maria was only fifty-two when she was diagnosed with a terminal and incurable disease. Her death was understood by those who knew her and narrated by 
her as the continuation of the death of her son, inscribed in the house where she lived. She died a few months later, after having painful symptoms and struggling to get proper treatment.

In the months Maria suffered, her house transformed as the illness got worse and increased her physical limitations. The food and the kitchen, which occupied a good portion of her time and conversation when she was healthy (Motta 2014), came to be the language in which Maria spoke of her death. She lamented that she no longer cooked, complained of the taste of food that other women prepared, and criticized the things they bought. The curtains were almost always drawn, the furniture was arranged so that Maria could support herself, and even the new bed that her husband bought made the bad house a house of dying.

Soon after Maria was buried, her husband and daughters built a small altar in the living room, just under Wellington's photo. They placed on it objects that had belonged to her, such as a rosary, a small statute of an angel, plastic flowers, and a photo in which she appeared, also smiling, looking at the camera, carrying the white dress in which she got married. The personal objects and the words written indicated the type of struggle of which these people were the object. Maria's death required more material and symbolic investments, distinguishing it from a good death. As Morimoto (2021) describes, altars and object-memories constitute creative ways of house-ing, materializing multiple temporalities and moral values.

Maria's husband began a relationship with another woman soon after she died, creating a scandal. Her daughters quickly gathered Maria's belongings from the home, so that they would not be appropriated by the father's new partner or thrown away. The older daughter concluded a long and inflammatory discourse against the father by affirming: "This is my mother's house!" She broke off her relationship with him after his new girlfriend moved in.

This concluded a long process that shattered the chance of a decent future for Maria's family. To have a son involved with drug sales can represent the moral disgrace of a large group of people linked to him, especially the mother, who is considered the main source of education for her children, the means by which they result in men who are "workers" or "bandits" (Zaluar 1985; Feltran 2007). A deeper, prolonged mourning always falls on the progenitress (Vianna and Farias 2011) given that the connection through pregnancy and nursing is considered the most significant among all the relations among people.

Within a short time, the widower went to live in another state. The house in which Maria had spent her final years was sold less than a year after her death. It was transformed into a storage space for the beverage store next door. Little 
was left of the residence that I knew. Maria's two daughters, who had lived in the same favela, moved to other neighborhoods. Thus, the house-this arrangement composed of the material structure, the objects stored in it, the people, and the possibility of a good collective future - also died. The entire network in which Maria's house occupied a central place (Marcelin 1999; Motta 2014) disintegrated, not only ceasing to have a possible good future but failing to have one altogether.

Bad deaths spread out: from the death of one person to that of others, from people to homes, and from within the home to the streets and alleys. This incontinence also occurs in relation to the subjective experience of a loss that is transformed into a deep existential disturbance. The events, emotions, experiences, and materializations of these deaths - from altars to graffiti-reveal a world in which the existence of humans, homes, and places combine and make each other.

They also demonstrate the deep consequences of racialized police violence for bodies and house-ing processes. The number of youths, mostly Black, assassinated in Brazil is so large that scholars treat the phenomenon as genocide and warn of generational loss. The enormous number of bad deaths_-violent, avoidable, commonplace deaths - produces not only painful inscriptions of mourning on houses but also the combination of youth, masculinity, and Blackness as a mark of death's potentiality in still living bodies.

\section{ABSTRACT}

In Rio de Janeiro's favelas, where residents have experienced economic precarity and racialized police violence, "good deaths," wrought by natural causes and at old age, are distinguished from "bad deaths," which may take victims' entire families and houses. This essay chronicles the story of Maria who died at fifty-two, following the death of her youngest son at the hands of the police, and inquires into the generativity of mourning related to these two bad deaths. As graffiti and altars became spatial inscriptions of a new moralization of space, Maria's house gradually transformed from a substrate of life into a marker of death. In the end, the home died too, as it was sold and its attendant social relations were unmade. Bad deaths thus reveal the moral entanglement between families, communities, and the materiality of houses, as well as the severance of these ties in the face of violence and intergenerational loss. [racialized police violence; economic precarity; family ties; graffiti and public mourning; death of the home; Brazil]

\section{RESUMO}

Nas favelas do Rio de Janeiro, onde os moradores convivem com a precariedade econômica e a violência policial racializada, as "boas mortes", de causas naturais e em idade avançada, diferem das "mortes ruins", que podem atingir a família das 
vítimas e as próprias casas. Este ensaio conta a história de Maria, que morreu aos 52 anos, depois do assassinato de seu filho caçula pela polícia, e analisa como o luto dessas duas "mortes ruins" se perpetua. Assim como grafittis e altares se tornam inscrições de uma nova moralização do espaço, a casa de Maria foi se transformando de um substrato de vida em um signo de morte. Afinal, a casa também morre e suas relações sociais são desfeitas. "Mortes ruins" revelam articulações entre famílias, comunidades e a materialidade das casas, assim como o rompimento desses laços frente à violência e às perdas intergeracionais. [violência policial racializada; precariedade econômica; laços familiares; grafitti e luto público; morte da casa; Brasil]

\section{RESUMEN}

En las favelas de Río de Janeiro, donde las personas conviven con la precariedad económica y con la violencia policial racializada, las "muertes buenas" de causas naturales y en edad avanzada, se diferencían de las "muertes malas" que pueden golpear a las familias de las víctimas y a los propios hogares. Este ensayo cuenta la historia de María, que murió a los 52 años después de que su hijo menor fuera asesinado por la policía, y examina cómo se perpetúa el luto de estas dos "muertes malas". Al igual que los grafitis y los altares, que se convierten en inscripciones de una nueva moralización del espacio, la casa de María pasa de ser un sustrato de vida a un signo de muerte. Al fin y al cabo, la casa también murió y sus relaciones sociales se deshicieron. Las "muertes malas" revelan articulaciones entre las familias, las comunidades y la materialidad de las casas, así como la ruptura de estos vínculos ante la violencia y las pérdidas intergeneracionales. [violencia policial racializada; precariedad económica, lazos familiares; grafitis y luto público; muerte en casa; Brasil]

\section{NOTES}

1. All names are fictitious.

2. In 2019, 1,814 people were killed by state police: 78 percent were Black, 98 percent male, and 47 percent younger than twenty-nine (data from the Instituto de Segurança Pública - Institute of Public Security - of the State of Rio de Janeiro, https://www. ispvisualizacao.rj.gov.br:4434/Letalidade.html). The homicides of Black youth have been increasing throughout the country as well (Cerqueira and Coelho 2017).

3. In the words of Fernando Pessoa (2008): "Saudades, só portugueses / Conseguem senti-las bem, / Porque têm essa palavra / Para dizer que as têm” (Only the Portuguese feel saudades / Are able to feel them well, / Because they have this word / To say that they have them).

\section{REFERENCES}

Cerqueira, Daniel, and Danilo Santa Cruz Coelho

2017 “Democracia racial e homicídios de jovens negros na cidade partida." Rio de Janeiro: Ipea.

Costa Oliveira, Thiago da, and Carlos Fausto

2021 "Amazonian House-ing: A Visual Anthropology Essay." Cultural Anthropology 36, no. 4: 580-88. https://doi.org/10.14506/ca36.4.06. 
Feltran, Gabriel de Santis

2007 "Trabalhadores e bandidos: Categorias de nomeação, significados políticos." Revista Temáticas 30: 11-50. https://doi.org/10.20396/tematicas.v15i30.13649.

Marcelin, Louis Herns

1999 "A linguagem da casa entre os negros no Recôncavo Baiano." Mana 5, no. 2: 31-60. https://doi.org/10.1590/S0104-93131999000200002.

Morimoto, Ryo

2021 "Home Otherwise: Living Archives and Half-Life Politics in Post-Fallout Coastal Fukushima." Cultural Anthropology 36, no. 4: 573-79. https://doi.org/10.14506/ ca36.4.05.

Motta, Eugênia

2014 "Houses and Economy in the Favela." Vibrant: Virtual Brazilian Anthropology 11, no. 1: 118-58. https://doi.org/10.1590/S1809-43412014000100005.

2020 “Uma casa boa, uma casa ruim e a morte no cotidiano." Etnográfica 24, no. 3: 775-95. https://doi.org/10.4000/etnografica.9603.

Neiburg, Federico

2021 "Multiscale Home: Shifting Landscapes and Living-in-Movement in Haiti." Cultural Anthropology 36, no. 4: 548-55. https://doi.org/10.14506/ca36.4.02.

Pessoa, Fernando

2008 Quadras ao gosto popular. Porto Alegre, Brazil: L\&PM.

Vianna, Adriana, and Juliana Farias

2011 "A guerra das mães: Dor e política em situações de violência institucional." Cadernos Pagu 37: 79-116. https://doi.org/10.1590/S0104-83332011000200004.

Zaluar, Alba

1985 A máquina e a revolta: As organizações populares e o significado da pobreza. São Paulo: Brasiliense. 